\title{
In vitro Evaluation of Botanical Extracts, Animal Wastes, Organic and Inorganic Salts against Sclerotinia Rot of Rapeseed-Mustard Caused by Sclerotinia sclerotiorum (Lib) de Bary
}

\author{
P. Upadhyay* and A.K. Tiwari
}

Centre of advanced studies, Department of Plant Pathology, College of agriculture, GBPUA\&T Pantnagar- 263145, U.S. Nagar, Uttarakhand, India

*Corresponding author

\section{A B S T R A C T}

\section{Keywords}

Sclerotinia rot, Sclerotinia sclerotiorum, Rapeseed-Mustard, botanical extract, animal wastes, organic inorganic salts, management

Article Info

Accepted:

15 August 2019

Available Online:

10 September 2019

\begin{abstract}
Among various diseases of rapeseed mustard, Sclerotinia rot caused by Sclerotinia sclerotiorum is emerging out as a serious problem and a major constraint for production and productivity of this crop across the country. Due to increasing environmental concern and health hazard the old management solution of this disease in form of fungicides, need to be replaced with safe and eco-friendly management approach. So the present experiment was carried out for in vitro evaluation of botanical extracts, animal wastes products and organic and inorganic salts against the growth of pathogen. Among them botanical extracts (garlic bulb, onion bulb, neem kernel, eucalyptus leaves) and animal waste products (cow urine, cow dung, vermin wash), were evaluated in vitro at different concentration levels (1, 2.5 and $10 \%$ ) by poison food technique while, organic and inorganic non toxic salts (sodium bicarbonate, oxalic acid, calcium carbonate and calcium sulphate) were evaluated at three concentration levels $(0.2,0.5,1$ and $2 \%)$ by same method for mycelium inhibition test. Among them cow urine at 5\%, garlic bulb extract at $10 \%$ and sodium bi carbonate at $1 \%$ found effective with $100 \%$ inhibition of mycelial growth of the pathogen followed by cow dung at $10 \%$ concentration, calcium carbonate at $2 \%$ concentration with complete mycelia growth inhibition. Hence natural or eco-friendly products such as cow urin and garlic bulb extracts were found very effective in managing sclerotinia rot disease in vitro, which can further be evaluated under field conditions for confirmation to develop Integrated Disease Management (IDM) module for chemical free, safe and eco friendly management of Sclerotinia rot in future.
\end{abstract}

\section{Introduction}

Oil seed Brassicas are the most important Rabi oilseed crops of the country. Brassica spp. contributes over 13 per cent of the world's edible oil supply. India holds a premier position in global oilseed scenario accounting for 19 per cent of oilseed area and 9 per cent of oilseed production. Among them Rapeseed- mustard is the second largest oilseed crops after the groundnut crop and accounts for 25 per cent of total oil seed 
production in India. Rapeseed and Mustard are the most important sources of edible oil mainly used for culinary purpose.

Diseases and insects are among the most important factors in bringing down the acreage, production and productivity of Rapeseed and mustard in India. Among diseases the crop has been known to be severely damaged by some of the important diseases such as Downy mildew, White rust, Alternaria blight and Sclerotinia stem rot (Saharan et al., 1984; Kolte, 1985; Bisht et al., 1994). Among all these sclerotinia stem rot is turning out to be very serious constraint in the production and productivity of rapeseedmustard across the country. Sclerotinia rot of Indian mustard (Brassica juncia) caused by Sclerotinia sclerotiorum (Lib.) de Bary has been reported from major rapeseed and mustard growing areas of the world (Morrall et al.,1976; Horning, 1983; Regnault and Pierre, 1984; Kang and Chahal, 2000). In India, disease has been reported from Assam, Uttar Pradesh, Haryana, Punjab, Rajasthan and Madhya Pradesh. In Rajasthan it has been observed in almost all the districts where its incidence varied up to 72 per cent (Lodha et al., 1992; Krishnia et al., 2000; Shivpuri et al., 2000 and Ghasolia et al., 2004). In severe infection, it caused seed yield losses up to 74 per cent in the country (Chauhan et al., 1992; Singh, 1998; Kang and Chahal, 2000).

The pathogen is reported to have a wide host range and known to infect about 400 plant species (Kolte, 1985). But economical and consistent management of the disease is still a challenge for pathologists. The unique ability of the resting structure of fungi known as sclerotia, to withstand adverse climatic conditions and explosive pathogenicity of the fungi under favourable conditions facilitate them to be devastating pathogen on many crops. Sclerotia are the preferred structures for overwintering and ensure the long term survival of the pathogen under field conditions. By keeping all these points in mind management of this disease has become the need of the hour.

Earlier many workers reported management of Sclerotinia rot of mustard by the application of fungicides (Rajinder Singh et al., 1994). Chattopadhyay et al., (2002) and many other scientists reported fungicides and biological treatment to be effective against the pathogen. But continuous and long term use of fungicides can be hazardous to plant as well as human health in long run because of their residual toxic effect and wide spectrum activity. The continuous use of these potentially hazardous chemicals is posing an increasing threat to environment by possible harmful impact on wild life and other nontarget beneficial micro-organism. Thus in recent years, an increasing consciousness about environmental pollution due to pesticides and development of fungicide resistant strains in plant pathogens has challenged plant pathologists to minimize the use of these pesticides and to search for ecofriendly tools for disease management. In this series botanical pesticides or plant extracts and animal waste products and many non toxic salts are being as vital components of integrated pest management programme due to their environment friendly approach that posses low persistence, biodegradability and low mammalian toxicity. Hence, use of botanicals and animal waste products for management of plant diseases is need for the research due to their easy availability, eco friendly nature, cost effective and safe for human as well as animal health.

\section{Materials and Methods}

\section{Botanical extracts/Plant extracts}

In order to acertain the bio-efficacy of botanical extracts with antifungal compounds and their distribution in different plant parts, the plant extracts viz., onion bulb (Allium 
sativum), Garlic bulb (Allium cepa), neem kernel (Azadirachta indica) and Eucalyptus leaves (Eucalyptus globules) were evaluated against the pathogen.

Plant extracts were prepared with the help of mortar and pestle by crushing plant parts and adding sterilized distilled water $(1: 1 \mathrm{w} / \mathrm{v})$. The extract was filtered through four layer of muslin cloth and was sterilized by passing it through sintered glass filters G1, G3 and G5 under aseptic conditions. The required concentration (1, 2.5 and 10\%) of each sterilized plant extract was prepared in test tubes. Each concentration of plant extract was mixed thoroughly in sterilized Potato Dextrose Agar (PDA) medium flasks before plating. The poured plates were kept for few hours to solidify. Three replications were maintained in each treatment. The test fungus was evaluated by poisoned food technique on PDA medium. For this a $5 \mathrm{~mm}$ mycelial disc of 5 days old culture of Sclerotinia sclerotiorum fungus was placed in centre of each Petri plate subsequently. The plates were incubated at $20 \pm 1^{0} \mathrm{C}$ for growth of the fungus. The diameter of the fungal colony was measured after $72 \mathrm{hrs}$ of incubation when growth in check plate is complete. Percent mycelial inhibition was calculated by using the following formula.

Per cent inhibition $(\%)=$

$\frac{\mathrm{C}-\mathrm{T}}{\mathrm{C}} \quad \mathrm{X} 100$

Where, $\mathrm{C}=$ growth of fungus in control

$\mathrm{T}=$ growth of fungus in treatment

\section{Animal wastes}

The animal waste viz., fresh cow urine, fresh cow dung and vermiwash were taken for the study. Fresh cow urine and cow dung as collected from a desi cow (Rathi breed) at 6 am in the morning and vermiwash was collected from Vermi compost unit GBPUAT, Pantnagar. Cow urine and cow dung were suspended in sterilized distilled water (1:1 w/v). The fresh cow dung suspension, cow urine and vermiwash were passed through G1, G3 and G5 sintered glass filters for sterilization. The final desired concentration of $1,2,5$ and 10 per cent of these animal wastes were prepared and evaluated against the test pathogen, using Poisoned food technique, observations were recorded and per cent mycelial inhibition was calculated as mentioned above.

\section{Organic and inorganic non toxic salts}

Among different non toxic chemicals inorganic salts viz. sodium bicarbonate, calcium carbonate and calcium sulphate and inorganic salts eg. oxalic acid were evaluated at different concentrations $(0.2,0.5,1$ and $2 \%)$ by poisoned food technique in PDA medium for radial growth inhibition as earlier of test fungus and per cent mycelial inhibition was calculated as mentioned above.

\section{Results and Discussion}

\section{Evaluation of botanical extracts}

The data (Table 1, Fig 1, Plate) revealed that among all the botanical extracts tested, garlic bulb extract completely inhibited (100\% inhibition) mycelial growth of the test pathogen followed by onion bulb extract $(20 \%$ inhibition) and neem kernel extract (17.7\% inhibition) at 10 per cent concentration. However, at 5 percent concentration only garlic bulb extract was found effective against pathogen with $74.2 \%$ mycelial growth inhibition. Hence all the treatments significantly reduced the mycelial growth of the pathogen only at 10 percent concentration. 
Table.1 Effect of botanicals/plant extract on the growth of Sclerotinia sclerotiorum under in vitro conditions

\begin{tabular}{|c|c|c|c|c|c|c|c|c|}
\hline \multirow[t]{3}{*}{ Plant extract } & \multicolumn{8}{|c|}{ Concentration (\%) } \\
\hline & \multicolumn{2}{|c|}{1} & \multicolumn{2}{|r|}{2} & \multicolumn{2}{|c|}{5} & \multicolumn{2}{|c|}{10} \\
\hline & $\begin{array}{l}\text { *Radial } \\
\text { growth }(\mathrm{mm})\end{array}$ & $\begin{array}{l}\text { *Inhibition } \\
(\%)\end{array}$ & $\begin{array}{l}\text { * Radial } \\
\text { growth } \\
(\mathrm{mm})\end{array}$ & $\begin{array}{l}\text { *Inhibition } \\
(\%)\end{array}$ & $\begin{array}{l}\text { *Radial } \\
\text { growth }(\mathrm{mm})\end{array}$ & $\begin{array}{l}\text { *Inhibition } \\
(\%)\end{array}$ & $\begin{array}{l}\text { * Radial } \\
\text { growth } \\
(\mathrm{mm})\end{array}$ & $\begin{array}{l}\text { *Inhibition } \\
(\%)\end{array}$ \\
\hline Allium sativum (Garlic) & 28.3 & $64(53.59)$ & 22.3 & $72(58.12)$ & 18 & $77.5(61.70)$ & 0.00 & $100(90)$ \\
\hline Allium cepa (Onion) & 67 & $16.25(23.73)$ & 64 & $20(26.50)$ & 59 & $26.25(30.78)$ & 56 & $30(33.20)$ \\
\hline $\begin{array}{l}\text { Azadirachta indica } \\
\text { (Neem) }\end{array}$ & 63 & $\begin{array}{l}21.25 \\
(27.420\end{array}$ & 57 & $28.75(32.41)$ & 57 & $28.75(32.39)$ & 54 & $32.5(34.73)$ \\
\hline $\begin{array}{l}\text { Eucalyptus globules } \\
\text { (Eucalyptus) }\end{array}$ & 80 & $0.00(0.00)$ & 80 & $0.00(0.00)$ & 68 & $15(22.75)$ & 65 & $\begin{array}{l}18.75 \\
(25.60)\end{array}$ \\
\hline \multirow[t]{2}{*}{ Check } & 80 & - & 80 & - & 80 & - & 80 & - \\
\hline & Pathogen $(\mathrm{A})$ & & & Concentration(B) & & & $\mathrm{AXB}$ & \\
\hline \multicolumn{9}{|l|}{ Per cent inhibition } \\
\hline CD (0.05) & 1.88 & & & 1.88 & & & 3.76 & \\
\hline CV (\%) & 6.54 & & & & & & & \\
\hline \multicolumn{9}{|l|}{ Radial growth } \\
\hline CD (0.05) & 2.33 & & & 2.33 & & & 4.66 & \\
\hline CV (\%) & 5.34 & & & & & & & \\
\hline
\end{tabular}


Table.2 Effect of animal waste on the growth of Sclerotinia sclerotiorum under in vitro conditions

\begin{tabular}{|c|c|c|c|c|c|c|c|c|}
\hline \multirow[t]{3}{*}{ Animal waste } & \multicolumn{8}{|c|}{ Concentration (\%) } \\
\hline & \multicolumn{2}{|c|}{1} & \multicolumn{2}{|r|}{2} & \multicolumn{2}{|c|}{5} & \multicolumn{2}{|c|}{10} \\
\hline & $\begin{array}{c}* \text { Radial } \\
\text { growth }(\mathrm{mm})\end{array}$ & $\begin{array}{c}\text { *Inhibition } \\
(\%)\end{array}$ & $\begin{array}{c}\text { *Radial } \\
\text { growth }(\mathrm{mm})\end{array}$ & $\begin{array}{c}\text { *Inhibition } \\
(\%)\end{array}$ & $\begin{array}{c}* \text { Radial } \\
\text { growth }(\mathrm{mm})\end{array}$ & $\begin{array}{c}\text { *Inhibition } \\
(\%)\end{array}$ & $\begin{array}{c}* \text { Radial } \\
\text { growth }(\mathrm{mm})\end{array}$ & $\begin{array}{c}* \text { Inhibition } \\
(\%)\end{array}$ \\
\hline Cow urine & 56 & $27.08(31.35)$ & 52 & $35(36.20)$ & 56 & $100(90)$ & 0.00 & $100(90)$ \\
\hline Cow dung & 60 & $25(29.9)$ & 60 & $26.6(31.08)$ & 53 & $33.75(35.51)$ & 0.00 & $100(90)$ \\
\hline Vermiwash & 62 & $17.75(24.9)$ & 60 & $25(29.9)$ & 58 & $27.5(31.62)$ & 33.3 & $58.3(49.80)$ \\
\hline \multirow[t]{2}{*}{ Check } & 80 & - & 80 & - & 80 & - & 80 & - \\
\hline & $\begin{array}{c}\text { Animal } \\
\text { waste (A) }\end{array}$ & & & Concentration(B) & & & $\mathrm{AXB}$ & \\
\hline \multicolumn{9}{|c|}{ Per cent inhibition } \\
\hline CD (0.05) & 1.59 & & & 1.84 & & & 3.19 & \\
\hline $\mathrm{CV}(\%)$ & 3.98 & & & & & & & \\
\hline \multicolumn{9}{|l|}{ Radial growth } \\
\hline CD (0.05) & 2.58 & & & 2.98 & & & 5.16 & \\
\hline $\mathrm{CV}(\%)$ & 6.38 & & & & & & & \\
\hline
\end{tabular}


Table.3 Effect of organic and inorganic salts on the growth of Sclerotinia sclerotiorum under in vitro conditions

\begin{tabular}{|c|c|c|c|c|c|c|c|c|}
\hline \multirow[t]{3}{*}{ on toxic chemical } & \multicolumn{8}{|c|}{ Concentration (\%) } \\
\hline & \multicolumn{2}{|c|}{0.2} & \multicolumn{2}{|r|}{0.5} & \multicolumn{2}{|c|}{1} & \multicolumn{2}{|c|}{2} \\
\hline & $\begin{array}{c}* \text { Radial } \\
\text { growth }(\mathrm{mm})\end{array}$ & $\begin{array}{c}\text { *Inhibition } \\
(\%)\end{array}$ & $\begin{array}{c}\text { * Radial } \\
\text { growth } \\
(\mathrm{mm})\end{array}$ & $\begin{array}{c}\text { *Inhibition } \\
(\%)\end{array}$ & $\begin{array}{c}* \text { Radial } \\
\text { growth } \\
(\mathrm{mm})\end{array}$ & $\begin{array}{c}\text { *Inhibition } \\
(\%)\end{array}$ & $\begin{array}{c}\text { * Radial } \\
\text { growth } \\
(\mathrm{mm})\end{array}$ & $\begin{array}{c}\text { *Inhibition } \\
(\%)\end{array}$ \\
\hline Sodium bicarbonate & 79.3 & $0.8(4.19)$ & 77.3 & $3.3(10.42)$ & 0.00 & $100(90)$ & 0.00 & $100(90)$ \\
\hline Oxalic acid & 78.6 & $1.63(7.22)$ & 77.3 & $3.33(10.37)$ & 51.6 & $35.41(36.39)$ & 36.6 & $54.1(47.39)$ \\
\hline Calcium sulphate & 79.6 & $0.4(2.09)$ & 79 & $1.23(5.12)$ & 80 & $0.00(0.00)$ & 80 & $0.00(0.00)$ \\
\hline Calcium carbonate & 78.6 & $1.63(5.79)$ & 25 & $68.08(55.64)$ & 26.6 & $85.41(68.06)$ & 0.00 & $100(90)$ \\
\hline \multirow[t]{2}{*}{ Check } & 80 & - & 80 & - & 80 & - & 80 & - \\
\hline & Chemical (A) & & & Concentration(B) & & & $\mathrm{AXB}$ & \\
\hline \multicolumn{9}{|l|}{ Per cent inhibition } \\
\hline CD (0.05) & 2.77 & & & 2.77 & & & 5.55 & \\
\hline CV (\%) & 10.21 & & & & & & & \\
\hline \multicolumn{9}{|l|}{ Radial growth } \\
\hline CD (0.05) & 4.67 & & & 4.67 & & & 9.35 & \\
\hline
\end{tabular}

**Mean of three replication; Values in parenthesis are angular transformed 
Fig 1: Effect of botanical / plant extracts on mycelial growth inhibition of
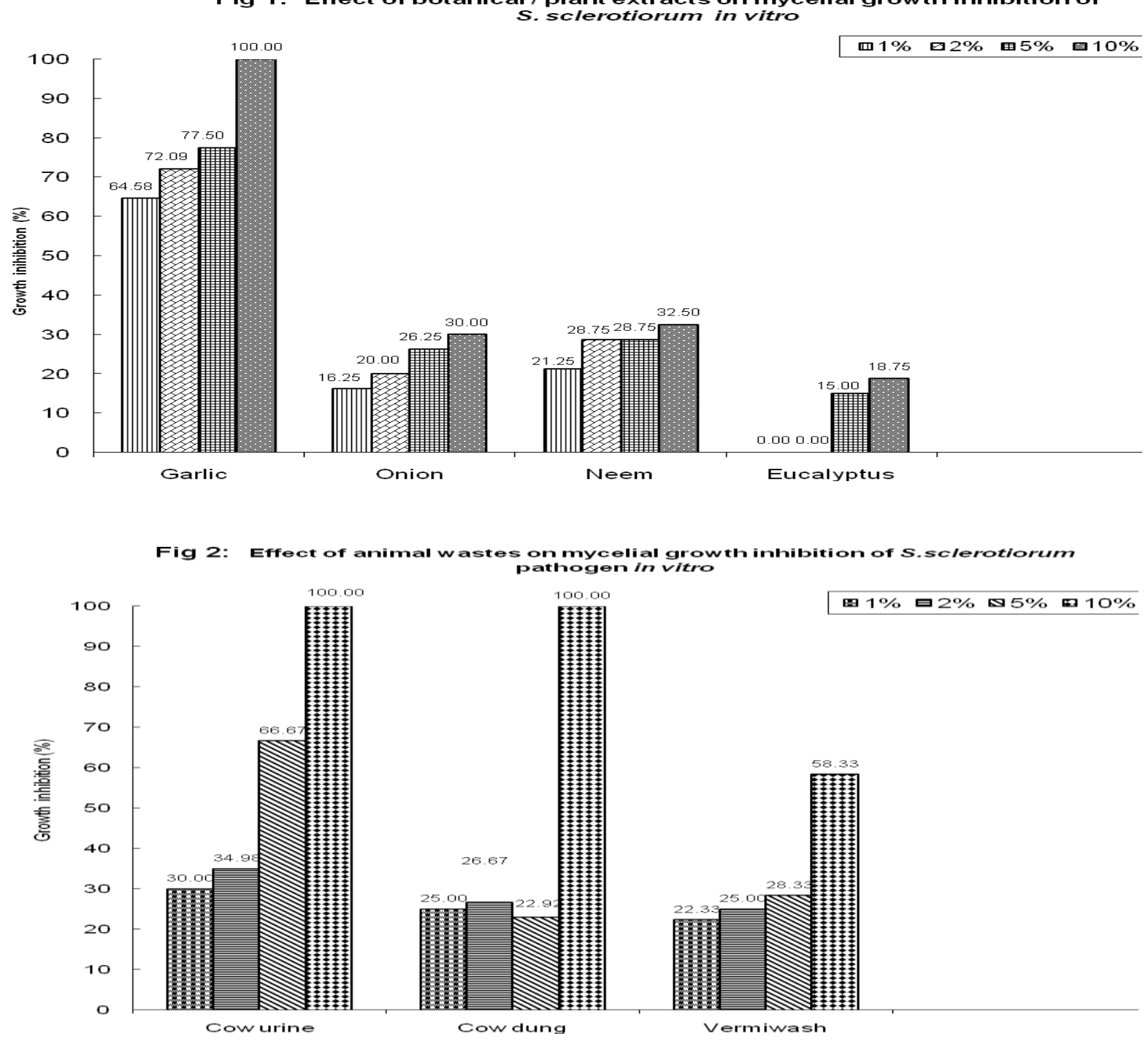

Fig 3: Effect of organic and inorganic salts on mycelial growth inhibition of $S$. sclerotiorum pathogen in vitro

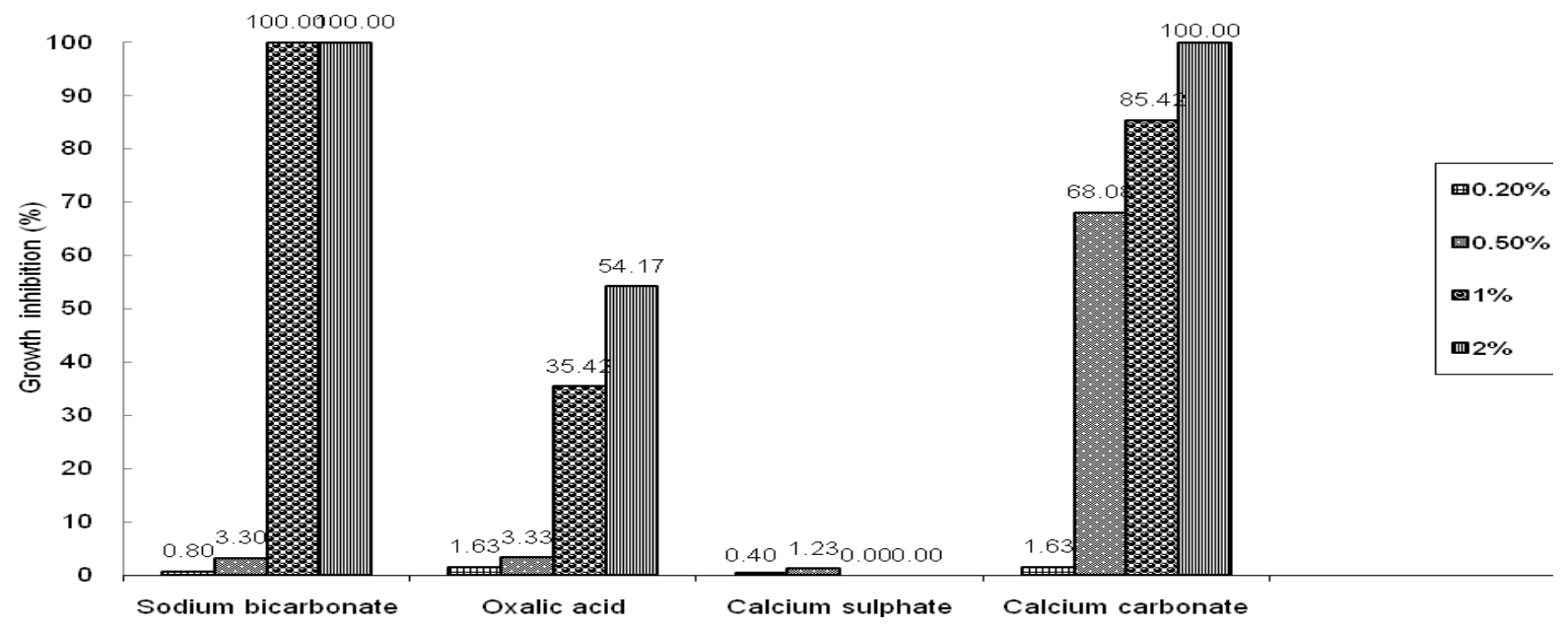


Plate.2

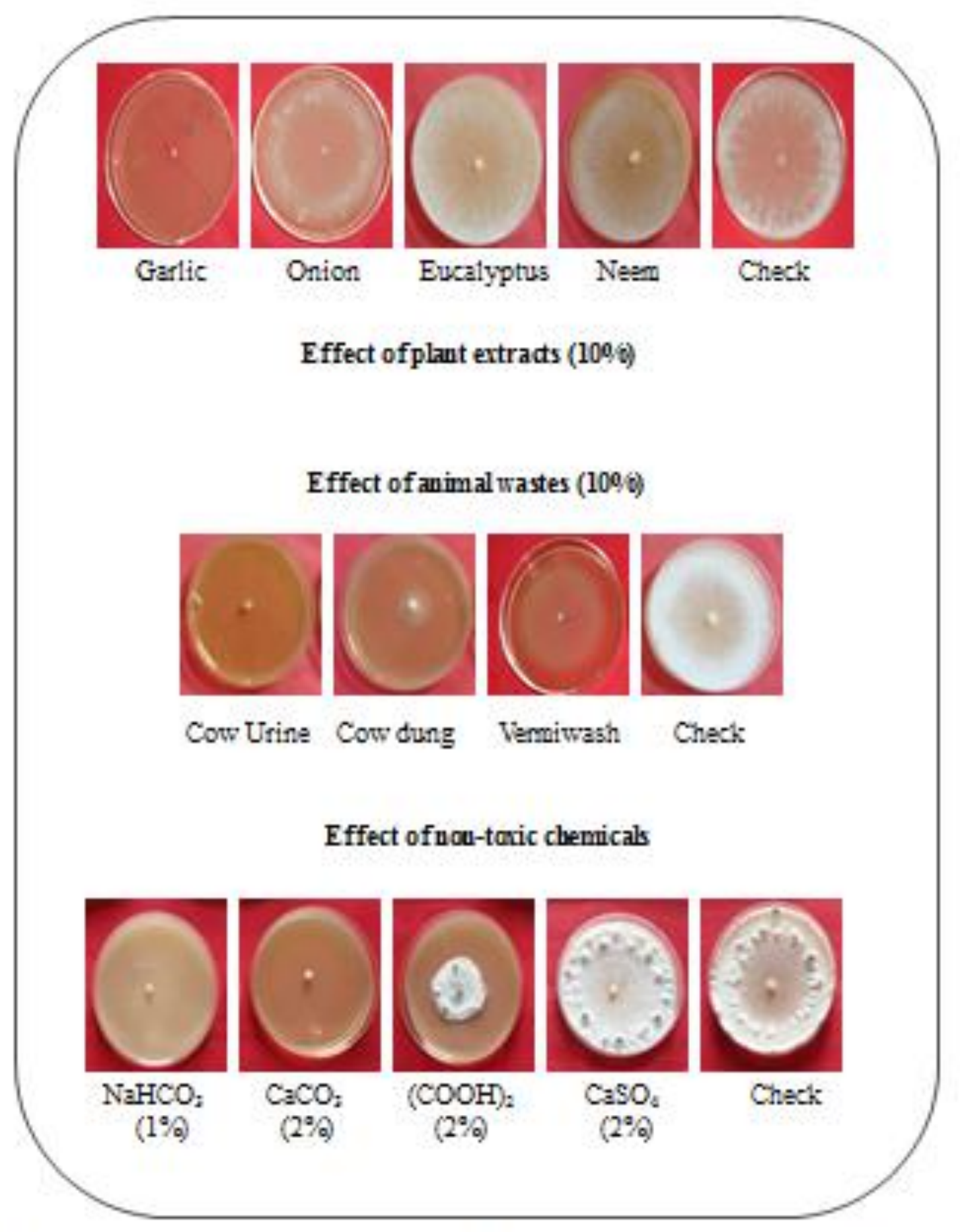

Evaluation of bio-products and noutaric chemicals against S.sclerotionom (EDAI) 
The findings of the earlier workers (Singh, 1979; Shivpuri and Gupta, 2001 and Dar et al., 2007) were also in accordance with the present findings as they reported that garlic bulb extract is the most effective plant extracts in inhibition of mycleial growth of the S. sclerotiorum. However, Pinto et al., (2008) observed that leaf extract of Eucalyptus citriodora completely inhibited mycelial growth of the pathogen at 0.1 per cent. The information obtained in the present investigation supports the effectiveness of garlic in reducing the fungal growth, whereas other botanicals did not show any marked reduction in the growth of the pathogen.

\section{Evaluation of animal wastes}

Among all the treatments viz., cow urine, cow dung and vermiwash tested in vitro the best results were obtained with the cow urine (100\% inhibition) at 5 per cent concentration followed by cow dung (100\% inhibition) and vermiwash (51.4\% inhibition) at 10 per cent concentration (Table 2, Fig 2, Plate). All the treatments significantly reduced the mycelial growth of the pathogen at all the concentrations except vermiwash (at 1\%). Banik et al. (2002) also observed antifungal activity of cow dung and cow urine against $S$. sclerotiorum in vitro. Complete mycelial inhibition of the pathogen was observed with cow urine, while 75.9 percent inhibition by cow dung which is more or less similar to the present findings.

\section{Evaluation of organic and inorganic salts}

Among all the treatments, complete mycelial inhibition (100\% inhibition) was observed with sodium bicarbonate and calcium carbonate at 1 and 2 per cent concentration respectively (Table 3, Fig 3, Plate). However, rest of the salts was found ineffective at all their concentrations except oxalic acid (2\%). These non toxic chemicals can be utilized as a better option for the management of $S$. Sclerotiorum.

In this in vitro study among the bio products which were evaluated against the pathogen cow urine at 5\%, garlic bulb extract at $10 \%$ and sodium bi carbonate at $1 \%$ of concentration were found effective with $100 \%$ inhibition of mycelial growth. Rest of the bio products are also effective but at higher concentration. These bio products need to be tested under field conditions also for management of sclerotinia rot under natural environmental conditions and for preparation an IDM module for ecofriendly management of the disease. Along with this the efficacy of these bio pesticides can be compared with fungicides in vitro as well as under field condition for successful replacement of such hazardous chemicals with natural and ecofriendly bio products for managing the disease. As these products can be a potential substitute of chemicals in managing scletotinia rot. It will not only help in reducing hazardous effects of chemicals on environment and human health but will also ensure sustainable development of agriculture in long run .So it can be a potential and ecofriendly alternative for chemicals in managing this disease for future use.

\section{References}

Bisht, I.S.; Agrawal, R. C. and Singh, R. (1994).White rust (Albugo candida) severity in mustard (B. juncea) varieties and its effects on seed yields. Plant varieties and seeds. 7: 85-89.

Chattopadhyay,C.; Meena, P. D. and Sudheer, K. (2002). Management of Sclerotinia stem rot of mustard using eco-friendly strategies. J. Mycol. and Plant Pathol. 32: 194-200.

Chauhan, L.S.; Singh, J. and Chandra, D.R. (1992). Assessment of losses due to stem rot to yellow sarson. In: Proc. of National Symposium on Management of Microbes 
in Service of Mankind. Nov.19-21 Allahabad, pp. 65-66.

Dar,G.H; Ahangar,F.A. and Quzi,N.A. (2007). Efficacy of various botanicals against Sclerotinia sclerotiorum. Journal of Food Legumes, 20(1):119-120..

Ghasolia, R.P.; Shivpuri, A. and Bhargava, A. K. (2004). Sclerotinia rot of Indian mustard (Brassica juncea) in Rajasthan. Indian Phytopath. 57: 76-79.

Horning, H. (1983). Zur epidemiology and Bekafungder Weibstengelikeit (Sclerotinia sclerotiorum). Raps.1: 32-34.

Kang, I. S. and Chahal, S.S. (2000). Prevalence and incidence of white rot of rapeseed and mustard incited by Sclerotinia sclerotiorum in Punjab. Plant Dis. Res. 15: 232-233.

Kolte, S. J. (1985). Rapeseed-mustard and sesame diseases, In: Diseases of Annual Edible Oilseed Crops, CRC Press, Boca Raton, Florida: 135p.

Krishnia, S. K.; Meena, P.D. and Chattopadhyay, C. (2000). Seed- yield and yield-attributes of Indian mustard affected by Sclerotinia rot. J. Mycol. Pl. Pathol. 30: 265

Lodha, B. C.; Bhatanager, M. K.; Mathur, K.; Doshi, A.; Mathur, S.; Bairwa, L.N.; Sharma, D. and Trivedi, A. (1992). Plant Pathological thoughts and News. Deptt. of Plant Pathology, Rajasthan Collage of Agric., Udaipur (India). 52p.

Pinto, C.M.F.; Maffia, L.A.; Casali, V.W.D and Cardoso, A.A. (2008). In vitro effect of plant leaf extracts on mycelial growth and sclerotial germination of Sclerotium cepivorum. Journal of Phytopathology.146(8): 421-425.

Regnault, Y. and Pierre, J.G. (1984). Control of
Sclerotinia sclerotiorum (Lib.) de Bary on oilseed rape in France. In: Aspect of Applied Biology 6. Agronomy, Physiology, Plant Breeding and Crop Protection of Oilseed Rape. Wellesbourne: AAB, 335-360.

Saharan, G. S.; Kaushik, C. D.; Gupta, P. P. and Tripathi, N. N. (1984). Assessment of losses and control of white rust of mustard. Indian Phytopath. 37: 397.

Shivpuri, A.; Sharma, K.B. and Chhipa, H.P. (2000). Some studies on the stem rot (Sclerotiniasclerotiorum) disease of rapeseed/ mustard in Rajasthan. J. Mycol. Pl. Pathol. 30: 268.

Singh, H.N. and Saha, L.R. (1989). Evaluation of some fungicides against $\mathrm{S}$. sclerotiorum the incident of wilt and rot of knol-knol. Pesticides. 23: 44-45

Singh, H.N. and Saha, L.R. (1989). Evaluation of some fungicides against $\mathrm{S}$. sclerotiorum the incident of wilt and rot of knol-knol. Pesticides. 23: 44-45

Singh, R. S. (1998).Sclerotinia rots and wilts. In: Plant Diseases, $7^{\text {th }}$ edition, oxford and IBH Publishing, New Delhi. pp. 298-314.

Singh, R.; Tripathi, N.N. and Kaushik, C.D. (1994). Management of Sclerotinia rot of Indian mustard (Brassica juncea (L.) Czern and Coss.) by fungicides. Crop Res. 7: 276-281.

Singh, U.P.; Pathak, K.K.; Khare, M.N and Singh, R.B. (1979). Effect of leaf extract of garlic on Fusarium oxysporum f. sp. ciceri, Sclerotinia sclerotiorum and on gram seeds. Mycologia, 71(3): 556-564.

Singh, Y. (1998). Management of Sclerotinia rot of rapeseed and mustard through chemicals. Plant. Dis. Res. 13: 149-150.

\section{How to cite this article:}

Upadhyay, P. and Tiwari, A.K. 2019. In vitro Evaluation of Botanical Extracts, Animal Wastes, Organic and Inorganic Salts against Sclerotinia Rot of Rapeseed-Mustard Caused by Sclerotinia sclerotiorum (Lib) de Bary. Int.J.Curr.Microbiol.App.Sci. 8(09): 851-860.

doi: https://doi.org/10.20546/ijcmas.2019.809.102 